\title{
Responses to the Practice of Hate Speech at the Pancasila Youth Organization in Sidoarjo
}

\author{
Tis'a Nur Sya'bani ${ }^{1)}$, Chusnul Fitriawati ${ }^{2)}$, Dewati Yuni Ratnasari ${ }^{3)}$, Siti Maizul \\ Habibah 4) \\ Program Study of Pancasila Education and Citizenship, Faculty of Social Sciences and Law, State \\ University of Surabaya, Jl. Potatoes, Surabaya, Indonesia 1,2,3,4) \\ sitihabibah@unesa.ac.id
}

\begin{abstract}
The practice of hate speech is not only carried out in the real world but also through the virtual world. The number of suspects in hate speech cases is not foreign to our ears. Based on Police data during 2017, there were 3,325 cases of hate speech crimes. This figure increased $44.99 \%$ from the previous year, which amounted to 1,829 cases. Hate speech practices are always motivated by SARA (ethnic, race, religion) issues as Indonesia is a country based on pluralism or upholds diversity. This is to describe the response to the practice of hate speech at the Pancasila Youth Organization on Jl Raya Pahlawan No.82 Jetis, Lemahputro, Sidoarjo. Quantitative research method with data collection techniques through providing questionnaires (questionnaires) and interviews to respondents. The results showed that the response of members of the Pancasila youth organization about the practice of hate speech was quite good. this is also evidenced by the frequency distribution whose value reaches above $75 \%$ with the category of quite good in terms of insight into hate speech, and handling hate speech in the community.
\end{abstract}

Keywords: Hate Speech, Community Organizations, SARA

\begin{abstract}
Abstrak. Praktik ujaran kebencian (hate speech) ini tidak hanya dilakukan di dunia nyata tetapi juga melaui dunia maya. Banyaknya penetapan tersangka kasus ujaran kebencian (hate speech) tidak asing lagi di telinga kita. Berdasarkan data Polri selama 2017 terdapat 3.325 kasus kejahatan hate speech atau ujaran kebencian. Angka tersebut naik 44,99\% dari tahun sebelumnya, yang berjumlah 1.829 kasus Praktik ujaran kebencian (hate speech) selalu di latar belakangi oleh persoalan SARA (suku, ras, agama) sebagaimana indonesia merupakan negara yang berbasis pluralisme atau menjunjung tinggi kebaragaman.Tujuan penelitian ini yaitu untuk menggambarkan tanggapan tentang praktik ujaran kebencian (hatespeech) pada organisasi pemuda pancasila di Jl Raya Pahlawan No.82 Jetis, Lemahputro, Sidoarjo. Metode peneitian kuantitatif dengan keknik pengumpulan data melalui memberikan angket (kuisioner) dan wawancara kepada responden. Hasil penelitian menunjukkan respon anggota organisasi pemuda pancasila tentang praktik ujaran kebencian cukup baik. hal ini juga dibuktikan dengan persebaran frekuensi yang nilainya mencapai diatas $75 \%$ dengan kategori Cukup baik dalam hal wawasan tentang ujaran kebencian, dan penanganan ujaran kebencian di masyarakat.
\end{abstract}

Kata Kunci: Ujaran Kebencian, Organisasi Masyarakat, SARA 


\section{INTRODUCTION}

Indonesia is a country consisting of various ethnic groups, religions, races and cultures. The condition of a pluralistic society is the hallmark of the Indonesian nation in carrying out the life of the nation and state. The attitude of tolerance between communities must be upheld in every interaction carried out by the Indonesian people. The attitude of tolerance is the binder, the builder of the unity and integrity of this diverse Indonesian nation. However, the reality that occurs in society shows that there are many intolerance attitudes, one of which is hate speech. Hate speech is speech that contains hate, is offensive and is carried out in a blazing manner that is intended to cause a certain impact,

Freedom in cyberspace raises new problems, namely hoaxes and hate speech. People are very easy to spread information that is not clear and the truth is conveyed hate speech(Herawati, 2016). This is in line with Eriyanto's research, namely Hate speech is also part of marginalization where a person or group of people is described as bad (Eriyanto, 2011: 124). The forms of hate speech found included insults, inciting, political provocation, defamation, blasphemy, and spreading hoaxes which were classified into four topics, namely political, social, economic and religious issues.(Ningrum, Suryadi, \& Chandra Wardhana, 2019). Actors who spread hoaxes and hate speech are not only done by criminals, many are also done by those who are just for fun, attacking politically, voicing their hearts, or just looking for sensations (Sutantohadi, Alief \& Wakhidah, Rokhimatul, 2017). The main challenge for automatic detection of hate speech on social media is the separation of hate speech from offensive language examples(Davidson, Warmsley, Macy, \& Weber, 2017). In Umrah research, it is stated that:hate speech on Social Media Networks is an insult to the head of state of the Republic of Indonesia. The offenses that can be punished are those who insult or attack the president and vice president personally, not those who criticize policies (Umrah, 2019).

Prevention of hate speech can be done preventively and repressively, this is in line with what was stated by Gunawan in his research, namely The police can take preventive measures in the form of preventive measures; and If preventive measures cannot solve various problems that arise from hate speech, then members of the Police can act repressively by referring to several existing laws and regulations.(Gunawan, 2020). Hate speech itself is very close to guaranteeing the right of opinion and expression which has been widely recognized as a standard of human rights. However, the guarantee of these rights does not mean that there is freedom without restrictions. mistakes in placing the size of speech, speech, statements can violate the boundaries of opinion and expression (Anam and Hafiz, 2015). Therefore, the National 
Police Chief issued a Hate Speech Circular which aims to protect human rights because in a democratic life it does not mean free without rules. However, democracy also has limitations so as not to violate the law and other human rights (Retnaningsih, 2015).

The practice of hate speech is not only carried out in the real world but also through the virtual world. The number of suspects in hate speech cases is not foreign to our ears. The government issues laws and circulars on hate speech through Article 27 paragraph (3) of the ITE Law, Article 45 paragraph (1) of the ITE Law and the Chief of Police Circular (SE) number SE/6/X/201(Mawarti, 2018). In the research conducted by Permatasari,shows the implementation of the ITE law has been adjusted to the objectives of the 1945 Constitution, however, in solving the problem of hate speech it is always tied to the rubber article, namely articles 27,28 and 29 of the ITE Law.(Permatasari \& Wijaya, 2019).

The practice of hate speech is always motivated by the issue of SARA (ethnicity, race, religion) as Indonesia is a country based on pluralism or upholds diversity. However, this diversity is often used to divide the nation. The young generation as millennials have a big responsibility for the future of the nation. This stems from research that states Many people have expressed concern that enforcing laws against hate speech will recreate the oppression of the past where SARA was used to suppress political opposition.(Ahnaf \&
Suhadi, 2014). Public space on social media no longer only functions as an arena for communication, where thoughts and knowledge are exchanged for values in a dialogical, independent and democratic manner. Its existence has been partially displaced by the power of capitalist economics and pragmatic politics to achieve certain goals that are instant, at the expense of its sociocultural values and aesthetics.(Kusumasari \& Arifianto, 2020). Youth who are currently increasingly eroded by the era of modernization. Morality that has been blinded by instant technology and easily accessible information without any filter of facts. Therefore, the role of youth is very much needed as a unifying agent in the nation and state. Likewise, the role of youth in Sidoarjo district.

Sidoarjo is a city that has a pluralistic social structure. Therefore, the culture likes to gather, to form a group with a specific purpose to become something that is inherent in society. Therefore, community organizations have a very large influence on the social and political environment of the people in Sidoarjo Regency. both youth community organizations, educational community organizations, non-educational community organizations and so on. The largest community organization in East Java is the Pancasila Youth Organization which has branches in various districts/cities in East Java. Sidoarjo is one of the cities where there are 
Pancasila youth organizations that are actively engaged in social activities.

Prejudice of hate speech has a significant effect on the political attitudes of novice voters, while belief in hoaxes has an insignificant effect on the political attitudes of novice voters.(Astrika \& Yuwanto, 2019)The Sidoarjo Pancasila Youth Organization is a space for Sidoarjo youths to uphold and develop Pancasila values which are currently starting to fade in the social structure of society. This is done in order to realize the integration of society in the nation and state. The existence of community organizations has been embedded in the social structure of the Sidoarjo community considering its existence is very much needed as support as well as encouragement for the community in the nation and state. Thus, the community can influence and contribute directly to the enforcement of Pancasila values.

\section{RESEARCH METHODS}

The research method used in this research is descriptive quantitative research method, namely by finding information about existing symptoms, clearly defined goals to be achieved, planning the approach, collecting data as material for making reports. According to Sugiyono (2016: 117) population is a generalization area consisting of objects or subjects that have certain qualities and characteristics set by researchers to be studied and then drawn conclusions. The population in this study were all members of the Sidoarjo Pancasila Youth Organization board.The sampling used in this research is using a simple random sampling technique. The simple random technique is a technique that gives every member of the population an equal chance to be selected as a sample.In this research, the data collection method used ish questionnaires (questionnaires) and open interviews to the object under study.

The variables contained in this study are ResponseHate Speech Practices as a single variable. The practice of hate speech is an act carried out by containing discriminatory elements against a certain party. While at the Pancasila Youth Organization Organisasias a criterion variable. The Pancasila Youth Organization can be interpreted as a community organization (ormas) in the field of youth that moves to uphold the values of Pancasila, especially in the Sidoarjo area.The data analysis technique carried out by the researcher was using quantitative descriptive analysis by providing an overview in the form of the percentage calculation of the variable sub-chapter indicator, namely the response of the Pancasila Youth Organization to the practice of hate speech.

This research conducted in Location The basecamp of the Pancasila youth organization Sidoarjo which is located on Jl. Raya Pahlawan No.82, Jetis, Lemahputro, 
Sidoarjo District, Sidoarjo Regency and carried out for 5 months.

\section{DISCUSSION}

The presence of social media as a forum for talking and exchanging information with one another certainly has a very positive impact, but on the other hand, social media is also an arena for the delivery of opinions, hate speech, and fake news (hoax).(Pakpahan, 2017). Based on the results of the calculation of the value of the data obtained from the respondent organizationyoung man pancasila sidoarjo show that the distribution of the frequency distribution The response of the Pancasila Youth Organization in Sidoarjo is known to have a minimum value of 29 and a maximum value of 47 , this indicates a relatively high range of maximum and minimum values. then the average value or mean taken from the total number of values divided by the number of values produces a number of 39.3 with a median or middle value of 41.5 , the mode or highest value of the entire data is 43. thus the standard deviation of the data is obtained of 5,30055. The normality test of the data was carried out through calculations through the Lilifors test because the data amounted to less than 35 with the following calculations; The highest value of $\mathrm{F}(\mathrm{X})$ $\mathrm{S}(\mathrm{X}) \mid$ as a normality test number, that is 0.15439 . With the value of the lilifors test quantile, $=0.05 ; \mathrm{N}=16$ i.e.0.2215. So that it can be obtained $0.15439<\mid 0.2215$ If Ho is accepted, Ha is rejected, then the population of the Pancasila Youth Organization in Sidoarjo is normally distributed. Testing the validity of the questionnaire questions was carried out through the calculation of the T-Correlational test and showed that there were 9 valid items and 5 invalid items.

As partfrom Agent of Change, youth are pioneers in creating a conducive atmosphere in society without any elements that lead to the practice of hate speech. Based on the results of calculations that have been processed, it is proven that the Pancasila Youth Organization has broad insight into the nature of hate speechthatalone. So that there is no effect if hate speech appears in various conditions and situations that exist in society.

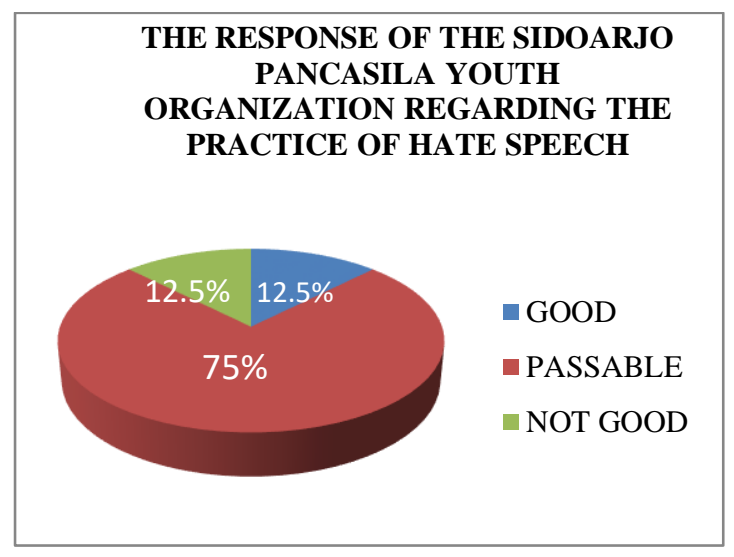

Diagram 1. Response Circle Diagram of Hate Speech Practices at the Pancasila Youth Organization Sidoarjo

This is also evidenced by the results of the frequency distribution in the diagram above which states that $75 \%$ of respondents know the nature or origin of the emergence of hate speech so that the level of knowledge of 
the Pancasila Youth Organization can be said to be good.

In this study, it was proven that the elements and influences caused by hate speech did not significantly affect the Pancasila youth organization. However, members of the Pancasila Youth Organization have concerns about the practice of hate speech that occurs in the Sidoarjo district community. This is evidenced by only $12.5 \%$ of all respondents who do not know well about the practice of hate speech. it means that the level of awareness has begun to build in the youth, especially the youth of Pancasila in Sidoarjo about the impact of the practice of hate speech. most of the respondents have a strategy in overcoming the impact caused by hate speech and are able to spread it with good knowledge.

Attitude as a youth is part of the reflection of the nation, if the youth has a positive attitude, it will reflect this nation which has a good character as well. This is also reflected in the attitude of the youth of Pancasila in Sidoarjo. In accordance with the description of the brief interview with members of each youth group, they stated the same thing, that hate speech occurs due to different views, such as different views on politics, religion, and so on. So that it is also an evaluation for youth on how to maintain the unity and integrity of the nation, which is diverse in ethnicity, religion, race, and culture, even though they have differences in views. So the solution in this case is to maintain communication and tolerance and maintain harmony in society as a bulwark against hate speech.

\section{CONCLUSION}

Based on the results of research and data processing that has been carried out, it shows that the response of members of the Pancasila youth organization about the practice of hate speech is quite good. this is also evidenced by the frequency distribution whose value reaches above $75 \%$ with the category of quite good in terms of insight into hate speech, and handling hate speech in the community.

\section{REFERENCES}

[1] Ahnaf, M. I., \& Suhadi. (2014). Isu-isu Kunci Ujaran Kebencian (Hate Speech): Implikasi terhadap Gerakan Sosial Membangun Toleransi. Harmoni: Jurnal Multikultural \& Multireligius.

[2] Anam, M. Choirul \& Hafiz, Muhammad. (2015). Surat Edaran Kapolri Tentang Penanganan Ujaran Kebencian (Hate Speech) Dalam Kerangka Hak Asasi Manusia. Jurnal Keamanan Nasional. Vol. 1, No. 3. Hal. 341364.

[3] Astrika, L., \& Yuwanto, Y. (2019). Ujaran Kebencian dan Hoaks: Signifikasinya terhadap Pemilih Pemula di Kota Semarang. Jurnal Ilmiah Ilmu Pemerintahan. https://doi.org/10.14710/jiip.v4i2.5433

[4] Davidson, T., Warmsley, D., Macy, M., \& Weber, I. (2017). Automated hate speech detection and the problem of offensive language. In Proceedings of the 11th International Conference on Web and Social Media, ICWSM 2017.

[5] Gunawan, H. (2020). Tinjauan Yuridis terhadap Ujaran Kebencian (Hate Speech) di 
Media Sosial dikaitkan dengan Kebebasan Berpendapat dan UU No 19 Tahun 2016 Tentang Perubahan Atas Undang-Undang Nomor 11 Tahun 2008 Tentang Informasi Dan Transaksi Elektronik. Res Nullius Law Journal.

https://doi.org/10.34010/rnlj.v2i1.2923

[6] Herawati, D. M. (2016). Penyebaran Hoax dan Hate Speech sebagai Representasi Kebebasan Berpendapat. Promedia.

[7] Kusumasari, D., \& Arifianto, S. (2020). Makna Teks Ujaran Kebencian Pada Media Sosial. Jurnal Komunikasi. https://doi.org/10.24912/jk.v12i1.4045

[8] Mawarti, S. (2018). FENOMENA HATE SPEECH Dampak Ujaran Kebencian. TOLERANSI: Media Ilmiah Komunikasi Umat Beragama. https://doi.org/10.24014/trs.v10i1.5722

[9] Ningrum, D. J., Suryadi, S., \& Chandra Wardhana, D. E. (2019). KAJIAN UJARAN KEBENCIAN DI MEDIA SOSIAL. Jurnal Ilmiah KORPUS. https://doi.org/10.33369/jik.v2i3.6779

[10] Pakpahan, R. (2017). Analisis Fenomena Hoax Diberbagai Media. Konferensi Nasional Ilmu Sosial \& Teknologi (KNiST).

[11] Permatasari, I. A., \& Wijaya, J. H. (2019). Implementasi Undang-Undang Informasi dan Transaksi Elektronik Dalam Penyelesaian Masalah Ujaran Kebencian Pada Media Sosial. Jurnal Penelitian Pers Dan Komunikasi Pembangunan. https://doi.org/10.46426/jp2kp.v23i1.101

[12] Retnaningsih, Hartini. (2015). Ujaran Kebencian Ditengah Kehidupan Masyarakat. Jurnal Info Singkat Kesejahteraan Sosial. Vol. 7, No. 21. Hal. 9-12.

[13] Sutantohadi, Alief \& Wakhidah, Rokhimatul. (2017). Bahaya Berita Hoax Dan Ujaran Kebencian Pada Media Sosial Terhadap Toleransi Bermasyarakat. Jurnal Pengabdian Masyarakat. Vol.1, No.1. Hal. 1-5.

[14] Umroh, F. (2019). Ujaran Kebencian (Hate Speech) pada Jejaring Media Sosial. Riset.Unisma.Ac.Id.
[15] Widayati, Lidya suryani. (2018). Ujaran Kebencian : Batasan Pengertian Dan Laranganya. Jurnal Info Singkat Terhadap Isu Aktual Dan Strategis. Vol.10, No.6. Hal. 1-6. 